A RCHIWA, BIBLIOTEKI

I MUZEA KOŚCIELNE 111 (2019)

https://doi.org.10.31743/abmk.2019.111.06

\author{
MARCIN A. KLEMENSKI* - KRAKÓW
}

\title{
AUGUSTIANIE-EREMICI W DZIERŻONIOWIE DO CZASÓW REFORMACJI
}

\begin{abstract}
Streszczenie
W niniejszym artykule prezentowane są dzieje klasztoru pw. św. Marka należącego do zakonu augustianów-eremitów. Omówione są dzieje fundacji, donacji rycerskich i szlacheckich, kwestie budowy kompleksu majątkowego we wsiach Podgórzno i Piława Dolna. Przedstawiono również sylwetki zakonników związanych z miejscowym klasztorem. Klasztor został zlikwidowany w 1525 roku na skutek postępującej Reformacji, jednak majątek klasztorny został przez samych zakonników rozprzedany, stąd też w późniejszym okresie stracili szanse na jego restytucję w Dzierżoniowie i w okolicach.
\end{abstract}

Słowa kluczowe: augustianie-eremici; Dzierżoniów; Śląsk; reformacja; klasztory

Przypadająca w 2017 roku okrągła rocznica 500-lecia wystąpienia słynnego augustianina-eremity Marcina Lutra skłoniła mnie do zwrócenia uwagi na śląskie placówki zakonu augustianów-eremitów ${ }^{1}$, które w dotychczasowej historiografii nie cieszyły się zbytnim zainteresowaniem historyków Kościoła.

* Marcin A. Klemenski - mgr historii; Instytut Historii, Uniwersytet Jagielloński w Krakowie; e-mail: mklemenski@poczta.onet.pl

https://orcid.org/0000-0001-8529-4762

${ }^{1}$ Bardzo wiele zamieszania w badaniach historycznych nad dziejami Kościoła i poszczególnych kongregacji zakonnych, szczególnie w tych prowadzonych przez polskich badaczy, wprowadził fakt, że historycy nie przestrzegali skrupulatnie terminologii zakonnej w przypadku zakonów podporządkowanych regule św. Augustyna. Pod hasłem augustianie ujmowali praktycznie wszystkie zakony kanonicze, jak i eremickie, co doprowadzało często do kuriozalnych sytuacji, kiedy to klasztory kanonickie są opisywane jako klasztory eremickie i odwrotnie. Niestety nadal dominuje ten chaos terminologiczny, gdyż zdarza się, że niektórzy historycy konsekwentnie piszą o augustianach, mając na myśli zakonników ze zgromadzenia kanoników regularnych (na Śląsku kongregacji arrowezyjskiej-opactwo NMP na Piasku, Żaganiu i w Kłodzku, później od XV wieku również kanoników regularnych kongregacji laterańskiej). Chlubnym wyjątkiem są prace Anny Pobóg-Lenartowicz, która konsekwentnie używa zapisu kanonicy regularni, thumacząc się tym, że używanie formy 
W dotychczasowej literaturze dzieje dzierżoniowskiego klasztoru były słabo rozpoznane, niewiele uwagi poświęcono augustianom-eremitom w monografiach dziejów Dzierżoniowa ${ }^{2}$. Wynika to przede wszystkim $\mathrm{z}$ ubogich zasobów źródeł - część z nich została opublikowana w Landbuchu księstw świdnickiego i jaworskiego ${ }^{3}$, natomiast pojedyncze, nieopublikowane dokumenty znaleźć można w zbiorach Archiwum Państwowego ${ }^{4}$, jak i w Archiwum Archidiecezjalnym we Wrocławiu ${ }^{5}$. Mała liczba źródeł nie pozwala nam na zrekonstruowanie pełnych dziejów konwentu - jednak możemy pozwolić sobie na szczątkowe odtworzenie dziejów majątkowych, relacji z rycerstwem, rozpoznać skład osobowy konwentu, jak i poznać okoliczności likwidacji klasztoru.

Trzeba zwrócić uwagę, że zakon augustianów-eremitów miał nietypowa genezę, ponieważ powstał $\mathrm{w}$ dniu 1 marca 1256 roku na skutek wielkiej unii mniejszych zgromadzeń eremickich ${ }^{6}$. Zakon bardzo szybko się rozwijał, już w 1256 roku utworzono cztery prowincje: Galię, Spanię, Germanię i Italię, z kolei w 1299 roku, z inicjatywy ówczesnego generała zakonu bł. Augustyna Novellusa, Germanię podzielono na cztery mniejsze prowincje: bawarską, kolońską, reńskąszwabską i turyńsko-saską7. Sląskie placówki zostały wcielone do prowincji bawarskiej. W 1431 roku prowincjał bawarski Jerzy z Schöntal (Valle Speciosa),

augustianie mija się z celem w przypadku Wrocławia, gdzie mamy do czynienia $\mathrm{z}$ opactwem kanoników regularnych na Piasku, jak i z konwentem augustianów-eremitów (A. Pobóg-Lenartowicz, Kanonicy regularni na Śląsku. Życie konwentów wśląskich klasztorach kanoników regularnych wśredniowieczu, Opole 1999, s. 24). W przypadku niemieckiej historiografii od początku praktycznie mamy do czynienia z rozróżnianiem tych zakonów: Augustiner-Chorherren, jak i Augustiner-Eremiten.

${ }^{2}$ Dzierżoniów. Zarys monografii miasta, red. S. Dąbrowski, Wrocław-Dzierżoniów 1998; J. Swastek, Dzierżoniów, w: Encyklopedia katolicka, t. 4, red. F. Gryglewicz, Lublin 1983, kol. 599; E. Chabros, Zakony średniowiecznego Dzierżoniowa, Dzierżoniów 2003; E. Hasse, Chronik der Stadt Reichenbach in Eulengebirge, Reichenbach 1929; W. Schwedowitz, Chronik der katolischen Gemeinde zu Reichenbach, Reichenbach 1909.

${ }^{3}$ Landbuch księstw świdnickiego i jaworskiego, t. 2: 1385-1395, wyd. T. Jurek, Poznań 2000; Landbuch księstw świdnickiego i jaworskiego, t. 3: 1396-1407, wyd. T. Jurek, Poznań 2007.

${ }^{4}$ Archiwum Państwowe we Wrocławiu (dalej: APWr), Rep. 39, nr 39, 41; Rep. 103, nr 188; Rep. 39, nr 39, 41; Rep. 132a, Depozyt miasta Dzierżoniowa, nr 16 (56), 31 (70); Zbiór Klosego, nr 95.

${ }^{5}$ Archiwum Archidiecezjalne we Wrocławiu (dalej: AAWr), Sygn. IX Akta parafii i miejscowości, Dzierżoniów, nr 1 1710-1729 Akten betreffend Ansprüche der Augustiner-Eremiten gegenüber den Kreuzherren; nr 2 1730-1748 Ansprüche der Augustiner-Eremiten.

${ }^{6}$ Bullarium Ordinis Eremitarum S. Augustini. Periodus formationis 1187-1256, hrsg. B. van Luijk, Würzburg 1964 (Cassiciacum, Bd. 18), s. 128-130; A. Kunzelmann, Geschichte der Deutschen Augustiner-Eremiten, Tl. 1, Das dreizehnte Jahrhundert, Würzburg 1969 (Cassiciacum, Bd. 26), s. 11-37; D. Gutiérez, Geschichte des Augustinerordens, Bd. 1, t. 1, Die Augustiner im Mittelalter 1256-1356, Würzburg 1985, s. 27-47

${ }^{7}$ H. Fros, Augustyn Novellus, w: Encyklopedia katolicka, t. 1, red. F. Gryglewicz, Lublin 1973, kol. 1115-1116; Kunzelmann, Geschichte, s. 134-200; Gutiérez, Geschichte, Bd. 1, t. 1, s. 62-72; H. Tüchle, Zur Geschichte der bayerischen Provinz der Augustinereremiten im Jahrhundert vor der Reformation, w: Scientia Augustiana. Studien über Augustinus, den Augustinismus und den Augustinerorden. Festschrift P. Dr. theol. Dr. phil. Adolar Zumkeller OSA zum 60. Geb., hrsg. C.P. 
by ułatwić administrację dość rozległą prowincją, która obejmowała Bawarię, Śląsk, Czechy, Morawy, Polskę, Austrię i Chorwację, utworzył dziewięć wikarii ${ }^{8}$. Pierwszy śląski klasztor augustianów-eremitów powstał w Grodkowie przed 1294 rokiem $^{9}$, kolejny w 1299 rokou w Chojnowie ${ }^{10}$. Trzecim z kolei był konwent w Dzierżoniowie, a najpóźniejszą metrykę ma klasztor we Wrocławiu, który był fundacją Karola IV, stworzoną na mocy dokumentu z dnia 24 listopada $1351 \mathrm{roku}^{11}$.

Zanim przejdę do omawiania początków klasztoru augustianów-eremitów, warto zwrócić uwagę na sytuację kościelną w mieście. Jedyną parafią miejską był kościół św. Jerzego, wzmiankowany już w 1258 roku, prawdopodobnie kościół istniał już jako centrum wiejskiej parafii, która po lokacji miejskiej stała się farą ${ }^{12}$.

Początki klasztoru pod wezwaniem św. Marka w Dzierżoniowie są trudne w odtworzeniu. Przyjmuje się powszechnie, że powstał przed rokiem $1329^{13}$. Gabriela Wąs zakładała, że klasztor powstał między 1329 a 1349 rokiem $^{14}$, z kolei zaś Marek Cetwiński przyjął rok $1349^{15}$. Jednak znany jest falsyfikat z $1300 \mathrm{roku}$, w którym jest mowa o platea mendicancium ${ }^{16}$, być może był on wzorowany na oryginalnym dokumencie - można wówczas założyć, że augustianie-eremici przybyli do Dzierżoniowa w latach 90 . XIII wieku. W tym okresie powstały klasztory w Grodkowie i Chojnowie. Przemysław Wiszewski przypuszczał, że książę świdnicki Bolko I mógł być fundatorem konwentu, jednocześnie wykluczając udział Bolka II Małego w fundacji, ponieważ sprowadził on joannitów do tego miasta ${ }^{17}$. Co ciekawe, Ewa Chabros optowała również za tym, by za fundatora uznać księcia Bolka I, ponieważ za jego rządów powstał klasztor

Mayer, W. Eckermann, Würzburg 1975, s. 630-640; G. Uth, Szkic historyczno-biograficzny Zakonu Augustjańskiego w Polsce, Kraków 1930, s. 14.

${ }^{8}$ Uth, Szkic, s. 33-39.

${ }^{9}$ M.A. Klemenski, Augustianie-eremici w Grodkowie (ok. 1294-ok. 1524), „Studia Teologiczno-Historyczne Śląska Opolskiego", 36 (2016) z. 1, s. 217-226.

${ }^{10}$ M.A. Klemenski, Dzieje klasztoru augustianów-eremitów pod wezwaniem św. Krzyża w Chojnowie (1299-1535), „Perspectiva. Legnickie Studia Teologiczno-Historyczne”, 16 (2017) z. 1 (30), s. 74-84.

${ }^{11}$ APWr, Zbiór Klosego, nr 95, s. 14-15; Regesty Śląskie, t. 2, nr 558.

${ }^{12}$ M. Cetwiński, Pradzieje i średniowiecze, w: Dzierżoniów. Zarys monografii miasta, red. S. Dąbrowski, Wrocław-Dzieżoniów 1998, s. 41.

${ }^{13}$ Uth, Szkic, s. 38; Kunzelmann, Geschichte, Bd. 3, s. 53; P. Wiszewski, Zakony z terenów dawnego księstwa świdnicko-jaworskiego: życie zakonne od XIII do pierwszej ćwierci XVI w., Świdnica-Jawor 2001, s. 43; D. Adamska, Fundacje dewocyjne rycerstwa księstwa świdnicko-jaworskiego w średniowieczu, Wrocław-Poznań 2005, s. 96; R. Eysymontt, Kod genetyczny miasta. Średniowieczne miasta lokacyjne na tle urbanistyki europejskiej, Wrocław 2009, s. 292, jednak błędnie pisze o „opactwie augustianów”.

${ }^{14}$ G. Wąs, Zakony mendykanckie na Śląsku w średniowieczu, „Śląski Kwartalnik Historyczny Sobótka", 54 (1998) z. 3-4, s. s. 425.

${ }^{15}$ Cetwiński, Pradzieje i średniowiecze, s. 69.

${ }^{16}$ Schlesisches Urkundenbuch (dalej: SUb), Bd. 6, hrgs. H. Appelt, W. Irgang, Köln 1998, nr 79.

${ }^{17}$ Wiszewski, Zakony, s. 43. 
cysterski w Krzeszowie i klasztor klarysek w Strzelinie ${ }^{18}$. Uzasadniała też, że fundacja w Dzierżoniowie, mieście przygranicznym księstwa świdnickiego, miała $\mathrm{w}$ ten sposób sakralizować granice księstwa ${ }^{19}$. Jest to interesująca hipoteza, jednak nie przekonuje, ponieważ autorka nie przedstawiła żadnych dowodów. Pamiętać też należy, że mendykanci przybywali już do lokowanych miast, więc Dzierżoniów w chwili ich pojawienia się musiał posiadać prawa miejskie ${ }^{20}$. Kwestia nadania praw temu miastu wywołuje spore dyskusje w historiografii, według M. Cetwińskiego nastąpiło to między 1253 a 1266 rokiem $^{21}$; stąd w latach 90. XIII wieku augustianie-eremici mogli przybyć do Dzierżoniowa.

Sprawę komplikuje fakt, że w tym okresie (1292-1301) do Dzierżoniowa sprowadzono $\mathrm{z}$ inicjatywy biskupa wrocławskiego Jana Romki zakon bożogrobców, którzy zajęli szpital z kościołem Grobu Świętego i św. Barbary ${ }^{22}$. Przypuszczalnie mogło to być powiązane $\mathrm{z}$ faktem sprowadzenia augustianóweremitów, lecz brak dokumentów fundacyjnych nie pozwala na rozsądzanie tej sprawy.

Co ważne - w 1329 roku w dokumencie wspomniany jest augustiański przeor Mikołaj, więc z całą pewnością klasztor wtedy już istniał. Nie widzę zatem przeciwwskazań, by uznać, że klasztor św. Marka powstał w przedziale czasowym od lat 90. XIII wieku do 1329 roku.

Pierwsza wzmianka o nadaniu ziemskim dla konwentu pochodzi z 30 sierpnia 1349 roku. Wówczas toczył się spór między zakonnikami a plebanem Janem z Gubina. Dotyczył on przywilejów i praw kościelnych we wsiach leżących na terenie parafii dzierżoniowskiej. Dnia 30 sierpnia 1349 roku wystawił w tej sprawie instrument notarialny magister Teodoryk, syn Konrada de Hartha, kleryk diecezji wrocławskiej, i wówczas spór rozsądzono na korzyść augustianów-eremitów otrzymali wieś Podgórzno ${ }^{23}$. W celu ochrony interesów majątkowych 4 stycznia 1350 roku przeor Jan z Mostów (de Ponte) wraz z konwentem mianowali brata Jana z Nysy prokuratorem klasztornym, nadali mu również odpowiednie uprawnienia dotyczące gospodarki majątkiem zakonnym ${ }^{24}$. W 1369 roku zakonnicy, powołując się na przywilej cesarza Ludwika IV Wittelsbacha z 1339 roku,

${ }^{18}$ Chabros, Zakony, s. 14.

${ }^{19}$ Tamże, s. 14.

${ }^{20}$ Wyjątkową sytuacją w historii augustianów-eremitów jest fundacja klasztoru w wiejskim majątku Patollen (Groß Waldeck, ob. Osokino w obwodzie kaliningradzkim), jednak wynikało to z tego, że było to ważne miejsce pielgrzymkowe i zakonników sprowadzono do obsługi pątników. Zob. R. Kubicki, Uwagi na temat roli zakonów mendykanckich $w$ w duszpasterstwie na terenach wiejskich państwa zakonu krzyżackiego w Prusach, „Studia Historica Gedanensia”, 7 (2016) s. 17-37.

${ }^{21}$ M. Cetwiński, Początki Dzierżoniowa (Rychbachu), ,Śląski Kwartalnik Historyczny Sobótka”, 46 (1991) z. 3, s. 299; tenże, Reichenbach-Dzierżoniów. Pradzieje i średniowiecze śląskiego miasta, „Prace Naukowe WSP w Częstochowie. Zeszyty Historyczne”, 3 (1996) s. 37-38; tenże, Pradzieje i średniowiecze, s. 48-54.

${ }^{22}$ Tenże, Pradzieje i średniowiecze, s. 61.

${ }^{23}$ Národni Archiv Praha, Řad Maltézsky - Listiny (dalej: ŘM-L), nr 99. Korzystałem z zasobów strony www.monasterium.net (dostęp 06.08.2015).

${ }^{24}$ ŘM-L, nr 100. Błędnie E. Chabros odczytała tego Jana z Nysy jako Jana von Miess, zob.: Chabros, Zakony, s. 16. 
postarali się o wyłączenie spod jurysdykcji wójta dzierżoniowskiego swojej wsi Podgórzno ${ }^{25}$. Z 27 maja 1386 roku pochodzi informacja, że Albert z Ratyzbony, ówczesny prowincjał bawarski, nakazał dzierżoniowskim augustianom-eremitom ekskomunikować osoby, które wtargnęły do kościoła klasztornego, by ująć złodzieja, nie bacząc na sacrum miejsca ${ }^{26}$. Trzeba wspomnieć, że dzierżoniowscy augustianie-eremici musieli $\mathrm{w}$ jakiś sposób współdziałać $\mathrm{z}$ joannitami, którzy również w tym mieście mieli swoją komendę. Powiązania te są zauważalne, gdy uświadomimy sobie, że większość dokumentów augustianów-eremitów z tego miasta zachowało się w archiwum joannitów w Pradze. Z pewnością musieli oni posiadać jakąś wspólnotę interesów bądź też zawarli konfraternię, jak to było w ówczesnym zwyczaju ${ }^{27}$. Dnia 7 stycznia 1387 roku Mikołaj von der Peilow nadał zakonnikom folwark Trebekowle w Dolnej Piławie, pochodzący z wiana swojej żony Małgorzaty, świadkowali wówczas Mikołaj z Cisowa, Heidenryk de Tschertitz, bracia Henryk i Bernard Wiltberg ${ }^{28}$. W 1394 roku Mikołaj von der Peilow sprzedał przeorowi Janowi Eichhornowi czynsz z Piławy Dolnej29. W dniu 1 kwietnia 1394 roku Gunczel Wüstenhube ofiarował augustianom-eremitom kolejny folwark w Dolnej Piławie wraz z trzema łanami ${ }^{30}$. Trzy lata później, 8 lutego 1397 roku przeor Jan Eichhorn wykupił od Mikołaja Herdana i jego żony Katarzyny półtora grzywny czynszów, opatrzonych na sumę dwudziestu grzywien na folwarkach sąsiadujących $\mathrm{z}$ folwarkiem Trebekowle $\mathrm{w}$ Dolnej Piławie ${ }^{31}$. Wspomniany wyżej Mikołaj von der Peilow, w dniu 13 sierpnia 1397 roku przekazał na ręce Jana Eichorna kolejny folwark w Dolnej Piławie ${ }^{32}$; w tym samym dniu przeor ten zrezygnował z pięciu i pół grzywny czynszu z dóbr w Dolnej i Górnie Piławie na rzecz świdnickiego altarysty Andrzeja Boule $^{33}$. Z kolei 17 grudnia 1401 roku pleban z Bystrzycy Kłodzkiej, Henryk Halle, przekazał swoje czynsze z Piławy augustianom-eremitom, niestety, nie jest wspomniane, w jakiej wysokości one były. Świadkowali wówczas rycerze Heidenryk Tschertitz, Hentschelin z Wałdowa, Jan Stewitz i Henryk Kreppel ${ }^{34}$. 14 września 1402 roku przeor Piotr Czireckir i szafarz Konrad Schuffener

${ }^{25}$ Chabros, Zakony, s. 14.

${ }^{26}$ Kunzelmann, Geschichte, Bd. 3, s. 52-53.

${ }^{27}$ M. Starnawska, Duszpasterstwo parafialne joannitów w miastach Ślaska i Wielkopolski w późnym średniowieczu, w: Klasztor w kulturze średniowiecznej Polski. Materiały z ogólnopolskiej konferencji zorganizowanej w Dąrowie Niemodlińskiej w dniach 4-6 XI 1993 przez Instytut Historii WSP w Opolu i Instytut Historyczny Uniwersytetu Wrocławskiego, red. A. Pobóg-Lenartowicz, M. Derwich, Opole 1995, s. 124, przyp. 78. Joannici zostali sprowadzeni do Dzierżoniowa przez księcia świdnickiego Bolka II w 1338 roku, który im nadał prawo patronatu nad farą miejską.

${ }^{28}$ Landbuch księstw świdnickiego i jaworskiego, t. 2, $\mathrm{nr} 386$.

${ }^{29}$ Tamże, nr 1168. Świadkowali wówczas Heidenryk Tschertitz, Jerzy Lubschitz oraz świdniccy altarzyści Jan Croschwicz i Jerzy Lubschitz.

${ }^{30}$ Tamże, nr 1338. Świadkami byli m. in. rycerze Heynemann de Hof oraz Konad Tschirnhaus.

${ }^{31}$ Landbuch księstw świdnickiego i jaworskiego, t. 3, nr 183.

${ }^{32}$ Landbuch księstw świdnickiego i jaworskiego, t. 2, nr 1168. Świadkami byli: Mikołaj z Cisowa, Ulryk Schwabe, Bernard Wiltperg i Henryk Młodszy z Wieściszowic.

${ }^{33}$ Tamże, nr 1169.

${ }^{34}$ Tamże, t. 3, nr 1211. 
otrzymali od prezbitera Stanisława sześć grzywien rocznego czynszu z folwarku Gunczela Wüstenhubego w Dolnej Piławie na wspomnienie duszy zmarłego plebana świdnickiego Jana Kolmasa, z obowiązkiem odprawiania mszy ku czci Maryi $^{35}$. W 1407 roku przeor Mateusz otrzymał od Konrada von Reibnitza grzywnę rocznego czynszu z Tuszyna koło Dzierżoniowa ${ }^{36}$. Dnia 18 października 1410 roku w Świdnicy, starosta świdnicko-jaworski, Janko z Chotěmic, potwierdził ufundowanie przez Mikołaja Schonewaldta i jego żonę Annę Mszy świętych za zbawienie duszy brata Mikołaja. $Z$ tego tytułu przeznaczone miały być cztery grzywny corocznego czynszu z łaźni przy ul. Wrocławskiej ${ }^{37}$. Ci sami ofiarodawcy nadali 10 grzywien czynszu z dóbr Janisława Buloid[?] w Jordanowie Śląskim w weichbildzie niemczańskim, potwierdzili to rajcy dzierżoniowscy 29 kwietnia $1440 \mathrm{roku}^{38}$. Z kolei 18 maja 1414 roku Heyncze Sweinichen, dziedzic Jordanowa Śląskiego, potwierdził transakcję swojego poddanego Hannosa Henpila, który sprzedał braciom eremitom pół grzywny czynszu, płaconego co roku w dzień św. Walpurgi ${ }^{39}$. Jan von Peterswalde w 1417 roku sprzedał ówczesnemu przeorowi trzy grzywny rocznego czynszu z Pieszyc ${ }^{40}$.

Ten wykaz (przede wszystkim rycerskich) nadań jest rozszerzony w stosunku do opracowania Dagmary Adamskiej dotyczącego fundacji dewocyjnych rycerstwa świdnicko-jaworskiego ${ }^{41}$. Z tego spisu wynika, że augustianie-eremici z Dzierżoniowa, musieli mieć wyjątkowo dobre kontakty z Mikołajem von der Peilow, Mikołajem z Cisowa, Heidenrykiem de Tschertitz oraz z braćmi Wiltperg, gdyż często przewijają się w źródłach jako ofiarodawcy bądź też świadkowie nadań dla zakonników. Pozostali zaś pojawiają się sporadycznie jako świadkowie na dokumentach. Jednak zauważyć można, że augustianie-eremici utrzymywali kontakt z drobnym rycerstwem, jak również z przedstawicielami tak ważnych rodów jak zu Dohna, Tschirnhaus, czy Seidlitz. Na tle pozostałych śląskich placówek augustianów-eremitów akurat dzierżoniowski konwent ma najlepiej poświadczone w źródłach ślady kontaktów z rycerstwem.

Klasztor musiał uzyskać dość spore znaczenie w prowincji bawarskiej, skoro uznano go za miejsce godne, by w 1423 roku odbyła się tam kapituła prowincjalna, mimo że leżał nieco na uboczu prowincji. Podczas tego zgromadzenia przeprowadzono wybory nowego prowincjała, wikariuszy

${ }^{35}$ Tamże, nr 1312. Świadkami byli: Benesz zu Dohna, Friczko z Landeskrone, Mikołaj z Rybnicy, Herman z Chościszowic i Zygmunt Baumgarten.

${ }^{36}$ APWr, Rep. 39, nr 39, k. 72.

${ }^{37}$ APWr, Rep. 132a, Depozyt miasta Dzierżoniowa, nr 16 (56).

${ }^{38}$ Tamże, nr 31 (70).

${ }^{39}$ Tamże, nr 18 (58). Stanisław Dąbrowski odczytał Hannosa Henpila jako Hanusza Heynira, co jest oczywistym błędem paleograficznym, zob.: Dzierżoniów. Zarys monografii miasta, red. S. Dąbrowski, Wrocław-Dzierżoniów 1998, s. 74. Dodatkowo jest to cenny dokument dla dziejów śląskich augustianów-eremitów, ponieważ jest jedynym nam znanym chłopskim nadaniem na rzecz augustiańskich mendykantów.

${ }^{40}$ APWr, Rep. 103, nr 188.

${ }^{41}$ D. Adamska, Fundacje dewocyjne rycerstwa księstwa świdnicko-jaworskiego w średniowie$c z u$, Wrocław-Poznań 2005, s. 96-97. 
prowincjalnych, jak i wizytatora. Wiadomo, że na ten urząd kandydowali Bertold Puchhausen z Ratyzbony, Bertold z Monachium i Ulryk z Schöntal - wybrano wówczas Bertolda Puchhausena ${ }^{42}$. Oprócz tego również rozpatrywano kwestię reformy klasztoru w Pradze. Niestety nie wiadomo, w jakich dniach kapituła ta obradowała, w źródłach znajduje się tylko datę roczną.

Nieliczne są źródłowe ślady kontaktów zakonników $\mathrm{z}$ miejscowym mieszczaństwem. W 1440 roku rajcy miejscy Piotr Jost, Michał Weinhold, Jan Swed, Michał Sluchting potwierdzili nadanie czynszów z dóbr Janisława Buloid w Jordanowie Śląskim przez małżeństwo Schonewaldtów ${ }^{43}$. Z pewnością takich śladów kontaktów z mieszczaństwem było więcej, niestety w źródłach nie znajdujemy ich potwierdzenia. Jednak, jak pisze Przemysław Wiszewski, w świadomości mieszkańców klasztor eremitów musiał być na tyle ważnym miejscem, że w topografii miejskiej pojawiła się nazwa platea mendicantium ${ }^{44}$.

Ostatnia znana w źródłach darowizna dla klasztoru pochodzi z 1447 roku, wtedy to Jan Heyde w intencji zbawienia duszy swojego ojca Kaspra, przekazał roczny czynsz trzech grzywien z dóbr w Książnicy koło Dzierżoniowa ${ }^{45}$. Łącznie więc ze znanych nam źródeł wynika, że zakonnicy otrzymywali rocznie 28,5 grzywien z czynszów, oprócz tego komasowali dobra we wsi Dolna Piława i Podgórzno, co mogło wynikać z konsekwentnej strategii przeorów dzierżoniowskich, którzy w ten sposób chcieli stworzyć zwarty kompleks majątkowy ${ }^{46}$. Zwraca uwagę fakt, że wyjątkowo często rycerstwo dotowało klasztor, oczywiście, jeśli porównamy z donacjami rycerskimi na rzecz pozostałych śląskich klasztorów augustianóweremitów ${ }^{47}$. Ta swego rodzaju nadreprezentatywność rycerstwa może wynikać również z tego względu, że księstwo świdnicko-jaworskie może się szczycić wyjątkowym źródłem, jakim są Landbuchy, w których przechowano informacje o wszelkich transakcjach majątkowych na tym terenie. Z pewnością klasztor otrzymywał również donacje ze strony mieszczaństwa, jednak nie zachowały się żadne źródła, które by mogły je poświadczyć.

Z początkiem XVI wieku odżył konflikt klasztoru z parafią miejską. Plebani dzierżoniowscy (w okresie 1504-1520 byli to: Wincenty Jauer, Jan Mauer, Jakub i Mikołaj Hartwig) mieli pretensje o to, że augustianie-eremici inkasują dochody z dóbr kościelnych przynależnych parafii i że rada miejska nie wspiera plebanów $\mathrm{w}$ tym konflikcie ${ }^{48}$. Niestety nie znamy rozstrzygnięcia tej sprawy, prawdopodobnie przeszkodził $\mathrm{w}$ tym zbliżający się ruch reformacyjny.

Pewnym śladem nadchodzącej reformacyjnej burzy jest fakt, że rada miejska nie wspierała plebana $\mathrm{w}$ konflikcie $\mathrm{z}$ augustianami-eremitami na tle dochodów. Być może wówczas w okresie 1504-1520 powoli mieszczanie zaczęli przyglądać

${ }^{42}$ Kunzelmann, Geschichte, Bd. 3, s. 52-53.

${ }^{43}$ APWr, Rep. 132a, Depozyt miasta Dzierżoniowa, nr 31 (70).

${ }^{44}$ SUb, t. 6, nr 479; P. Wiszewski, Zakony, s. 43.

${ }^{45}$ APWr, Rep. 39, nr 41, k. 182-183.

${ }^{46}$ Adamska, Fundacje dewocyjne, s. 97.

${ }^{47}$ Klemenski, Augustianie-eremici w Grodkowie, s. 221-222; tenże, Dzieje klasztoru, s. 78-81.

${ }^{48}$ G. Pisarski, Czasy nowożytne (1500-1815), w: Dzierżoniów. Zarys monografii miasta, red. S. Dąbrowski, Wrocław-Dzierżoniów 1998, s. 82. 
się bliżej stosunkom kościelnym, z pewnością proces ten przyspieszył po 1517 roku. Już 20 kwietnia 1524 roku do Dzierżoniowa przybył słynny kaznodzieja Jan Hess, który w tym mieście przeprowadził pierwszą dysputę teologiczną z przedstawicielami miejscowego duchowieństwa (a więc z pewnością również z augustianami-eremitami $)^{49}$, niestety nie znamy tak dobrze szczegółów tej dysputy w przeciwieństwie do słynnej dysputy w kościele św. Doroty we Wrocławiu, przeprowadzonej również przez J. Hessa. W ciągu roku część zakonników przeszła na nowe wyznanie, a grupa zakonników, która ostała się przy katolicyzmie, została wygnana z miasta przez mieszczan, prawdopodobnie do klasztoru we Wrocławiu, bądź rozproszyła się po Śląsku ${ }^{50}$. W 1525 roku klasztor augustianów-eremitów został zlikwidowany $^{51}$.

Likwidacja majątku zakonnego w Dzierżoniowie przebiegła stosunkowo szybko. Już we wtorek po trzeciej niedzieli Wielkanocy 1525 roku wikariusz Pankracy Geyer udał się do Dzierżoniowa, gdzie dokonał przeglądu majątku klasztornego i za zgodą wspólnoty zakonnej św. Doroty we Wrocławiu sprzedał budynek klasztorny wraz z gruntami należącymi do tego klasztoru Wolfgangowi von Bitschen $\mathrm{z}$ Piskorzowa, jednak pod warunkiem, że w kościele zakonnym będą odbywać się nabożeństwa. W niedzielę po Wniebowzięciu NMP 1525 roku król Ludwik II Jagiellończyk potwierdził transakcję ${ }^{52}$. Rok później W. von Bitschen sprzedał budynek klasztorny radzie miejskiej, ta z kolei rozprzedaje działki poklasztorne. Sam obiekt był wielokrotnie przebudowywany na magazyny handlowe, lecz już w 1713 roku odbudowano kościół zakonny i nadano mu wezwanie Niepokalanego Poczęcia NMP ${ }^{53}$, który do dziś służy parafii farnej. Co ważne, w XVIII wieku, a dokładniej w latach 1710-1748, augustianie-eremici z morawskiego Brna prowadzili korespondencję z radą miejską Dzierżoniowa i joannitami w sprawie zwrotu majątku poaugustiańskiego, jednak nie doszło to do skutku z tego powodu, iż w roku 1525 doprowadzono do legalnej transakcji sprzedaży klasztoru, a nie bezprawnego przejęcia przez miasto ${ }^{54}$. Więc też nie było podstaw prawnych do zwrotu majątku.

Niewielu znamy wymienionych $\mathrm{z}$ imienia zakonników związanych z konwentem dzierżoniowskim. Najważniejszym urzędem w klasztorze był urząd przeora. Znamy ze źródeł imiona pięciu przeorów. Najstarsza wzmianka pochodzi z24 maja 1329 roku (jednocześnie jest to pierwsza w ogóle wzmianka o klasztorze), wówczas to wspomniany jest przeor Mikołaj ${ }^{55}$. Kolejnym był Jan z Mostów, który

${ }^{49}$ Tamże, s. 84.

${ }^{50}$ Tamże, s. 84-85.

${ }^{51}$ Wernicke, Die Augustiner-Eremiten, s. 54, Uhtenwoldt, Reichenbach, s. 354.

${ }^{52}$ Pisarski, Czasy nowożytne, s. 84-86.

${ }^{53}$ J. Swastek, Dzierżoniów, w: Encyklopedia katolicka, t. 4, red. F. Gryglewicz, Lublin 1983, kol. 599.

${ }^{54}$ AAWr, Sygn. IX Akta parafii i miejscowości, Dzierżoniów, nr 1 1710-1729 Akten betreffend Ansprüche der Augustiner-Eremiten gegenüber den Kreuzherren; nr 2 1730-1748 Ansprüche der Augustiner-Eremiten.

${ }^{55} \mathrm{CDS}$, Bd. 22, nr 4847. Jest to nadanie Piotra z Bielawy i Sinderama der Weisse, gdzie świadkował przeor Mikołaj wraz z okolicznymi plebanami: Hermannem dzierżoniowskim, Arnoldem bieliszowskim i Sifridem bielawskim. 
wzmiankowany był 4 stycznia 1350 roku $^{56}$. W okresie od 13 sierpnia 1394 do 8 lutego 1397 w źródłach znajdujemy postać przeora Jana Eichorna ${ }^{57}$. Natomiast 14 września 1402 r. występuje przeora Piotr Czireckir ${ }^{58}$. Ostatnim znanym imiennie przeorem był niejaki Mikołaj, wspomniany w roku 1407.

Dwukrotnie w źródłach pojawia się urząd podprzeora. Sprawował on władzę w klasztorze w zastępstwie przeora. Funkcję tę pełnili Henryk zwany Jozafat (4 stycznia 1350 roku $)^{59}$ oraz Konrad Schuffener (14 września 1402 roku) ${ }^{60}$.

Do najważniejszych urzędów klasztornych zaliczyć trzeba szafarzy (bądź też prokuratorów). Już w 1350 roku w Dzierżoniowie zakonnicy wybrali na szafarza Jana $\mathrm{z}$ Nysy, który, jak zapisano w dokumencie, miał zarządzać majątkiem klasztornym, dokonywać wszelkich niezbędnych zakupów, jak i dbać o aprowizację konwentu. Tenże dokument jest jedynym znanym nam dokumentem dla śląskich augustianów-eremitów z nominacją zakonnika na urząd klasztorny ${ }^{61}$.

Oprócz tego, z dokumentu z dnia 4 stycznia 1350 roku znamy imiona trzech braci. Byli to Jan ze Lwówka, Jan z Bozlicz oraz Henryk z Ligoty ${ }^{62}$.

W tym miejscu musimy się zastanowić nad kwestią pochodzenia zakonników. Przeor Jan, jak wiemy z pewnością, pochodził z Mostów. Kwestią dyskusyjną jednak pozostanie sprawa, gdzie ta miejscowość była położona. Pozostali przeorzy nosili nazwiska mieszczańskie: Eichhorn, Czireckir. Wśród braci znamy pochodzących z miast: Nysy i ze Lwówka Śląskiego; oraz ze wsi: Ligoty ${ }^{63}$ i Bozlicz ${ }^{64}$. Z miejscowego mieszczaństwa pochodził Schuffener. Dominuje tu więc znów element mieszczański, chłopskie pochodzenie mogli mieć pochodzący z wsi Ligota i Bozlicz, zwłaszcza że nie pełnili jakiś znaczących urzędów w klasztorze.

Oprócz wcześniej wspominanych zakonników należy wspomnieć o niejakim Janie Scultetusie z Dzierżoniowa. Do zakonu augustianów-eremitów wstąpił w Dzierżoniowie, został wysłany na studia do Wiednia, gdzie jest wzmiankowany w 1418 roku $^{65}$, i 31 sierpnia 1419 roku wspominany jest jako student zakonnego Studium w Bolonii ${ }^{66}$. Nie znamy daty ukończenia jego studiów. Jest to jedyna

${ }^{56}$ ŘM-L, nr 100; Chabros, Zakony, s. 16; Dzierżoniów, s. 69.

${ }^{57}$ Landbuch, t. 2, nr 1168, 1169; t. 3, nr 183.

${ }^{58}$ Landbuch, t. 3, nr 1312.

${ }^{59}$ ŘM-L, nr 100, Chabros, Zakony, s. 16; Dzierżoniów, s. 69.

${ }^{60}$ Landbuch, t. 3, $\mathrm{nr} 1312$.

${ }^{61} \mathrm{R} \mathrm{M}-\mathrm{L}, \mathrm{nr} 100$.

${ }^{62}$ Tamże.

${ }^{63}$ Jest to nazwa tak na Śląsku powszechna, że nie podejmuję się próby identyfikacji tej wsi.

${ }^{64}$ Niezidentyfikowana wieś. Niestety, trzeba przyznać, że brak słownika historyczno-geograficznego dla terenu Śląska mocno utrudnia takie badania, jednak warto dodać, że w ostatnich latach prowadzone są starania, by to zmienić, zob.: Stownik wsi ślaskich w średniowieczu, t. 1: Powiat lubiński, red. D. Nowakowski, Wrocław 2014.

${ }^{65}$ A. Zumkeller, Manuskripte von Werken der Autoren des Augustiner-Eremitenordens in mitteleuropäischen Bibliotheken, Würzburg 1966, s. 269.

${ }^{66}$ Kunzelmann, Geschichte, Bd. 3, s. 53. 
osoba z dzierżoniowskiego klasztoru, o którym możemy z pewnością stwierdzić, że ukończył studia. Adalbero Kunzelmann podał, że w klasztorze w Dzierżoniowie musiała znajdować się szkoła zakonna dla wikarii śląskiej ${ }^{67}$. Jednak w świetle źródeł nie jest to kwestia tak oczywista. Praktycznie żadne źródła śląskie o tym fakcie nie wspominają.

Mimo licznych zmian, zachował się do dziś budynek klasztoru augustianóweremitów. Został zbudowany w północnej części obwarowanego miasta, tuż przy murze miejskim. Jest to jedyny w całości zachowany klasztor augustianóweremitów na Śląsku. Posiada niezwykle interesujące rozwiązanie architektoniczne, mianowicie zbudowano jedno skrzydło klasztoru do zachodniej ściany kościoła św. Marka tak, że tworzą jeden blok. Klasztor i kościół był kryty wspólnym dachem dwuspadowym, $\mathrm{z}$ tym że dach nad kościołem otrzymał sygnaturkę, jako pewną formę wyróżnienia architektonicznego. Całość powstała $\mathrm{z}$ łamanego kamienia w drugiej ćwierci XIV wieku, część klasztorna została w późniejszym czasie obniżona i przebudowana na cele magazynowe i handlowe ${ }^{68}$. Jednak mimo to, daje nam to pewnie wyobrażenie, jak mogły wyglądać pozostałe, niewielkie konwenty w Chojnowie i w Grodkowie. R. Eysymontt zakładał, że lokalizacja klasztoru została starannie zaplanowana, ponieważ idealnie wpisuje się w oś sakralno-symboliczną miasta, w którą umieszczono farę, ratusz oraz właśnie klasztor augustianów-eremitów ${ }^{69}$.

Kończąc ten opis dziejów klasztoru św. Marka w Dzierżoniowie, trzeba zauważyć, że tak naprawdę są to szczątkowe informacje. Jednakże na tyle miarodajne, by sensownie zrekonstruować dzieje konwentu. Jak już wcześniej wspomniałem, dzięki Landbuchom możemy poznać liczne rycerskie donacje na rzecz klasztoru. Gorzej już wygląda sprawa relacji z mieszczaństwem, o których nie wiemy zbyt wiele. $Z$ tych szczątkowych śladów można wywieść, że zakonnicy mieli częsty kontakt z okolicznym duchowieństwem (zwłaszcza altarystami), jak również $\mathrm{z}$ plebanami miejskich i wiejskich parafii, niekoniecznie blisko położonych Dzierżoniowa (jak np. Bystrzyca Kłodzka). Jak również z zakonem joannitów, którzy w Dzierżoniowie mieli swój klasztor.

Klasztor powstał najprawdopodobniej w ostatnim dziesięcioleciu XIII wieku, a przestał istnieć w 1525 roku na skutek ówcześnie postępującej Reformacji. W dziejach klasztoru możemy zauważyć taką prawidłowość, że zakonnicy starali się komasować swoje dobra w okolicach wsi Piławy Dolnej. Konwent musiał w prowincji odgrywać znaczącą rolę, skoro w 1423 roku odbyła się w nim kapituła dla rozległej przecież prowincji bawarskiej, na której wybrano nowego prowincjała Bertolda Puchhausena. Również uwagę zwraca fakt, że stosunkowo bezproblemowo rozegrała się sprawa likwidacji klasztoru dzierżoniowskiego, według ówczesnych norm prawnych zakon wyprzedał majątek. Przez to w późniejszym czasie stracił argument dla odzyskania tychże gruntów.

Jednakże, jak pokazuje przykład klasztoru dzierżoniowskiego, dzieje niewielkich konwentów położonych na terenie Śląska wciąż wymagają badań,

\footnotetext{
${ }^{67}$ Tamże.

${ }^{68}$ Dzierżoniów, s. 199-200.

${ }^{69}$ Eysymontt, Kod, s. 295.
} 
wiele tych fundacji nie doczekało się monograficznych opracowań, jak również szerszego zainteresowania historyków (oczywiście mowa o klasztorach związanych ze szpitalnictwem bądź zakonami mendykanckimi, gdyż zakony mnisze były dość dobrze przebadane w ostatnich latach ${ }^{70}$ ).

\section{BIBLIOGRAFIA}

\section{Źródła}

\section{Archiwum Archidiecezjalne we Wroclawiu}

sygn. IX Akta parafii i miejscowości, Dzierżoniów nr 1 1710-1729 Akten betreffend Ansprüche der Augustiner-Eremiten gegenüber den Kreuzherren; nr 2 1730-1748 Ansprüche der Augustiner-Eremiten.

\section{Archiwum Państwowe we Wrocławiu}

Rep. 39, nr 39, 41;

Rep. 103, nr 188;

Rep. 39, nr 39, 41;

Rep. 132a, Depozyt miasta Dzierżoniowa, nr 16 (56), 31 (70);

Zbiór Klosego, nr 95.

\section{Národni Archiv Praha}

Řad Maltézsky - Listiny, nr 99

\section{Wydawnictwa zwarte}

Bullarium Ordinis Eremitarum S. Augustini. Periodus formationis 1187-1256, hrsg. B. van Luijk, Würzburg 1964 (Cassiciacum, Bd. 18).

Landbuch księstwświdnickiego i jaworskiego, t. 2: 1385-1395, wyd. T. Jurek, Poznań 2000. Landbuch księstw świdnickiego i jaworskiego, t. 3: 1396-1407, wyd. T. Jurek,Poznań 2007. Regesty Ślaskie, t. 2, red. W. Korta, Wrocław 1983.

Schlesisches Urkundenbuch, Bd. 6, hrgs. H. Appelt, W. Irgang, Köln 1998.

\section{Opracowania}

Adamska Dagmara, Fundacje dewocyjne rycerstwa księstwa świdnicko-jaworskiego $w$ średniowieczu, Wrocław-Poznań 2005.

Cetwiński Marek, Poczatki Dzierżoniowa (Rychbachu), „Śląski Kwartalnik Historyczny Sobótka", 46 (1991) z. 3, s. 285-300.

Cetwiński Marek, Pradzieje i średniowiecze, w: Dzierżoniów. Zarys monografii miasta, red. S. Dąbrowski, Wrocław-Dzierzoniów 1998, s. 37-78.

Cetwiński Marek, Reichenbach-Dzierżoniów. Pradzieje i średniowiecze śląskiego miasta, „Prace Naukowe WSP w Częstochowie. Zeszyty Historyczne”, 3 (1996) s. 21-66.

Chabros Ewa, Zakony średniowiecznego Dzierżoniowa, Dzierżoniów 2003.

Eysymontt Rafał, Kod genetyczny miasta. Średniowieczne miasta lokacyjne na tle urbanistyki europejskiej, Wrocław 2009.

${ }^{70} \mathrm{~Np} .:$ K. Kaczmarek, Konwent dominikanów w Brzegu w XIV-XV wieku, „Archiwa, Biblioteki i Muzea Kościelne”, 109 (2018) s. 243-267. 
Fros Henryk, Augustyn Novellus, w: Encyklopedia katolicka, t. 1, red. F. Gryglewicz, Lublin 1973, kol. 1115-1116;

Gutiérez David, Geschichte des Augustinerordens, Bd. 1, t. 1, Die Augustiner im Mittelalter 1256-1356, Würzburg 1985.

Kaczmarek Krzysztof, Konwent dominikanów w Brzegu w XIV-XV wieku, „Archiwa, Biblioteki i Muzea Kościelne", 109 (2018) s. 243-267.

Klemenski Marcin A., Augustianie-eremici w Grodkowie (ok. 1294-ok. 1524), „Studia Teologiczno-Historyczne Śląska Opolskiego", 36 (2016) z. 1, s. 217-226.

Klemenski Marcin A., Dzieje klasztoru augustianów-eremitów pod wezwaniem św. Krzyża w Chojnowie (1299-1535), „Perspectiva. Legnickie Studia Teologiczno-Historyczne”, 16 (2017) z. 1 (30), s. 74-84.

Kubicki Rafał, Uwagi na temat roli zakonów mendykanckich $w$ duszpasterstwie na terenach wiejskich państwa zakonu krzyżackiego w Prusach, „Studia Historica Gedanensia", 7 (2016) s. 17-37.

Kunzelmann Adalberto, Geschichte der Deutschen Augustiner-Eremiten, t. 1: Das dreizehnte Jahrhundert, Würzburg 1969 (Cassiciacum, Bd. 26).

Pisarski Grzegorz, Czasy nowożytne (1500-1815), w: Dzierżoniów. Zarys monografii miasta, red. S. Dąbrowski, Wrocław-Dzierżoniów 1998, s. 81-127.

Słownik wsi ślaskich $w$ średniowieczu, t. 1: Powiat lubiński, red. D. Nowakowski, Wrocław 2014.

Starnawska Maria, Duszpasterstwo parafialne joannitów w miastach Śląska i Wielkopolski w późnym średniowieczu, w: Klasztor w kulturze średniowiecznej Polski. Materiaty $z$ ogólnopolskiej konferencji zorganizowanej $w$ Dabrowie Niemodlińskiej $w$ dniach 4-6 XI 1993 przez Instytut Historii WSP w Opolu i Instytut Historyczny Uniwersytetu Wrocławskiego, red. A. Pobóg-Lenartowicz, M. Derwich, Opole 1995, s. 115-126.

Swastek Józef, Dzierżoniów, w: Encyklopedia katolicka, t. 4, red. F. Gryglewicz, Lublin 1983, kol. 599.

Tüchle Hermann, Zur Geschichte der bayerischen Provinz der Augustinereremiten im Jahrhundert vor der Reformation, w: Scientia Augustiana. Studien über Augustinus, den Augustinismus und den Augustinerorden. Festschrift P. Dr. theol. Dr. phil. Adolar Zumkeller OSA zum 60. Geb., hrsg. C. P. Mayer, W. Eckermann, Würzburg 1975, s. 630-640;

Uth Grzegorz, Szkic historyczno-biograficzny Zakonu Augustjańskiego w Polsce, Kraków 1930.

Wąs Gabriela, Zakony mendykanckie na Śląsku w średniowieczu, „Śląski Kwartalnik Historyczny Sobótka", 54 (1998) z. 3-4, s. 415-434.

Wiszewski Przemysław, Zakony z terenów dawnego księstwa świdnicko-jaworskiego: życie zakonne od XIII do pierwszej ćwierci XVI w., Świdnica-Jawor 2001.

Zumkeller A., Manuskripte von Werken der Autoren des Augustiner-Eremitenordens in mitteleuropäischen Bibliotheken, Würzburg 1966, s. 269. 


\title{
THE ORDER OF AUGUSTINIAN HERMITS IN DZIERŻONIÓW TO THE TIME OF THE REFORMATION
}

\begin{abstract}
Summary
The following article presents the history of St Mark's Monastery, belonging to the Order of Augustinian Hermits. The paper examines the history of the foundation, the donations made by knights and noblemen, the issues of forming the estate in the villages of Podgórzno and Piława Dolna as well as the profiles of the monks connected with the local monastery. The monastery was liquidated in 1525 as a result of the Reformation. The monks, however, sold the estate of the monastery and that is why they had no chance to regain their property in Dzierżoniów and its environs.
\end{abstract}

Key words: the Order of Augustinian Hermits; Dzierżoniów; Silesia; the Reformation; monasteries 